\title{
HAVAYOLU ULAŞTIRMASI SEKTÖRÜNÜN REKABETÇI YAPISI: TÜRK HAVAYOLU ULAŞTIRMASININ AÇILIM DÖNEMİ ÜZERINNE BİR DEĞERLENDİRME
}

\section{Onur TUTULMAZ ${ }^{1}$}

\begin{abstract}
ÖZ
Gelişmiş modern bir ulaştırma sektörü, ekonominin önemli bir parçasını oluştururken, aynı zamanda da birçok sektörün altyapısını oluşturan, günümüzün önemli sektörlerinden biri durumundadır. Teknolojiyle yakından ilişkili olması ulaştırma ekonomisinin en önemli özelliklerindendir. Sektörün bu sürekli değişimi içeren yapısl, ulaștırma sektörünü konu alan çalışmalar içerisinde ilerleme ve performans değerlendirmesi çalışmalarının çokluğunu açıklayabilir. Bu çalışmanın bir amacı, geçen yüzyılın ikinci yarısında ulaștırma sektörü içinde önemli bir başarı hikâyesine konu olan havayolu sektörü içerisinde, Türk havayolu sektörünün durmunu ele almak ve Türk havayolu sektörü için önemli olan yüzyıl başındaki açılım döneminin başında, sektörün rekabetçi yapısına yönelik karşılaş̧ırmalı bir analizi ortaya koymaktır. Sektörün yaşadığı başarı hikâyesinin kilit noktası, sektörel oyuncular olan havayolu işletmelerinin arasından, rekabet ortamı içinde ayakta kalan en iyilerinin gösterdiği başarı olarak ortaya çıkmaktadır. Türk havayolu ulaştırması sektörünün incelemesi, havayolu sektörünün dünyadaki göz alıcı gelişmesini takip etmekte gecikmeler yaşandığını göstermektedir. Bu durum, sektöre yönelik genel bir değerlendirme yanında, sektörel aktörlerin rekabetçi yapısını temsilen girdi verimlilikleri üzerine yapılan değerlendirmede de kendini göstermekte olup, bu anlamda genel analizle uyum içerisinde sonuçlar vermektedir.

Anahtar Kelimeler: Ulaştırma Ekonomisi, Havayolu Ulaştırması, Sivil Havacıllk, Faktör Verimlilikleri, Türkiye. R40, L93,018.

\section{THE COMPETITIVE STRUCTURE OF AIR TRANSPORTATION SECTOR: AN EVALUATION ON THE LIBERALIZATION PERIOD OF TURKISH AIR TRANSPORTATION}

\footnotetext{
ABSTRACT

Transportation sector today, forms an important part of the economy. Moreover, transportation sector is in a close connection with many other sectors and serves as understructure for them. Its close connections to

1 Yrd. Doç. Dr., Hitit Üniversitesi, İktisadi ve İdari Bilimler Fakültesi, İktisat Bölümü, otutulmaz@gmail.com.
} 
technology leads to a continuous change and development in the transportation sector. This developing structure can explain the reason for high number of studies on detecting the change. One of the objectives of this paper is to evaluate the change and development of Turkish air transportation sector at the beginning of its reformation period. The study aims also to conduct an analysis on the competitive structure of the Turkish air transportation sector within a comparative manner. The critical point of the sectoral success can be seen as the achievement of the selected sectoral actors in the competitive atmosphere. The inspection of the Turkish air transportation shows that there are some delays in interpreting the global developments. This result is shared also by the results of the analysis of the comparative factor productivities.

Keywords: Transportation economics, Air Transportation, Civil Aviation, Factor Productivity Turkey. R40, L93, 018.

\section{GİRIS}

Ulaştırma sektörü, modern günlük yaşamın vazgeçilmez parçası olduğu gibi, ekonomi ve iş hayatının da önemli bir bileşimi durumundadır. İnsan yapımı teknolojiyle oluşturulan bir ulaştırma sektörü, bu teknolojiyle beraber sürekli gelişen ulaştırma modlarını içeren bir sektördür. İnsan faaliyetlerinin parçası olan ulaştırma sektörü, sosyal boyutunun yanında, gelişen dünyanın, endüstriyel sektörlerinin parçası ve altyapısı konumuna gelmiştir. İnsalığın gelişimi tarihinde ulaştırma olgusunun doğal güçlere dayandığı veriyken, buhar makinesinin icadıyla deniz ulaştırması ve demiryolu ulaştırmasında peş peşe önemli teknolojik değişimle makine gücüne geçildiği ve böylece günümüzdeki anlamıyla bir ulaştırma sektörünün şekillendiği görülmektedir.

Uzun insanlık tarihi içerisinde modern ulaştırma sektörünün ortaya çıkış sürecini son iki yüzyıllık sürece sığdırabilmekteyiz ${ }^{2}$. Bu

\footnotetext{
${ }^{2}$ Modern anlamda ulaştırma sektörünün doğuşunu buhar makinesinin icadından başlatmak, tabii güçlerden makine güçlerine dayanan yapıya dönüşümün başlangıç noktası olarak düşünüldüğünde anlamlıdır. İlk pratik buhar makinesinin 1769 yılında üretilmesi, sonrasında İngiltere'de ve ABD'de önemli gelişmeleri tetiklemiştir. 1802'de ilk deneme nitelikli lokomotifin Galler/İngiltere'de seferlerine başladığını görüyoruz. 1829 yılı içinde İngiltere'de yapımı gerçekleştirilen Roket (The Rocket) lokomotifi, at hızını geçmeyi başararak bu ünvanı alan ilk insan yapımı kara aracı olmuştur. Aynı sene içinde bu dizayn kullanılarak Amerika'daki ilk yolcu treni üretildi ve yine aynı yıl içerisinde Amerika'daki ilk demiryolu tamamlanmıș oldu. Özel girişimler ile Amerika'da baş döndürücü bir hızla yapımı gerçekleșen demiryolları 1860 yılı içerisinde 31000 mil uzunluğa ulaşmıștı. Öbür taraftan, Amerikalı girişimci Fulton, İngiliz buhar makinesini monte ederek yapımını gerçekleștirdiği Clermont adlı buharlı gemiyi 1807 yllında Hudson nehiri üzerinde
} 
değişim sürecinin başında, ulaştırmanın modern dönem öncesi tek ana direğini oluşturan denizyolu ulaştırmasının yanına bir demiryolu ulaştırması olgusu gelerek yerleşmiştir. Sektörün ilk büyük başarı hikâyesi, buhar makinesinin tetiklediği gelişmeler çerçevesinde etkileyici bir hızla büyüyen ve kısa sürede toplu ulaştırmanın merkezindeki yerini alan demiryolu ulaştırmasıdır.

19. yüzyılın önemli bașarı hikâyesi olan demiryolu ulaştırmasının bu başarı hikâyesinin iki benzerini yirminci yüzyıl içerisinde görebiliriz. Ulaştırma sektörünün gelişiminde buhar makinesinin icadıyla gelen birinci dönüşüm dalgası ardından gelen ikinci önemli dönüm noktası motor teknolojilerinin dünya savaşları sonrasında yaygın kullanımıyla birlikte ulaştırma olgusunun uğradığı köklü değişim olarak kabul edilebilir ${ }^{3}$ (bkz. Wright, 2004, s.71-90). $\mathrm{Bu}$ ikinci dalgayla birlikte, otomotiv teknolojisi gelişerek bireysel ulaştırma olgusunu toplumsal yaşamın merkezine yönelmesi, aynı zamanda uzun mesafe ulaştırması şekillenen bir havayolu ulaştırmasının gerçek anlamda doğuşu söz konusu olmuştur. ICAO'nun (Uluslararası Sivil Havacılık Teşkilatı) 1944 yılında kuruluşu havayolu sektörü için önemlidir. Ulaştırma modlarının gelişim ve dönüşümü süreci içerisinde üçüncü dönüm noktasını sektörel pazarı yeniden şekillendirmiş olan serbestleşme hareketlerinde görmek mümkündür (Winston, 2010, s.21). Serbestleștirme ${ }^{4}$ hareketleri sonucunda ulaştırma modları köklü

sefere aldı. 1811 yılında ise, bütün Amerika kıtasını kuzeyden güneye katediş süresini 40 günden 14 güne kadar indirmeyi bașaran ve Nicholas Roosvelt'in bizzat Amerika'da geliştirdiği buhar gemi işletmeye alındı. (Wright, 2004, s.2, 5-6).

3 Motor teknolojisinin temeli durumundaki içten yanmalı motorların (ICE) geliştirilmesi şüphesiz önemli bir teknoloji devrimi sayılabilir. Bununla beraber, ICE teknolojisi gelișimini de buhar makinesinin büyük ölçekte elde ettiği bașarıyı daha küçük ölçekte tekrarlama arzusuyla yine buhar makinesine dayandırmak mümkündür (bkz. Tutulmaz, 2013, s.92-3).

4 Serbestleștirme veya deregülasyon (liberalization-deregulation) hareketlerinin Amerikan tarihinde önemli bir yeri mevcuttur. Amerika'daki ulaștırma sektörünün baştan itibaren özel girișimlere dayanan bir yapısı mevcutken; dünya savașları ve sonrasında Keynezyen dönemin de etkisiyle federal otoritenin bütün ulaştırma sistemlerinde öne çıkması söz konusudur. Bu gelişmelere karşı çıkan liberal kanadın, iktisadi ekollere bağlı iklimin de değişimiyle beraber, 1960'ların ikinci yarısından itibaren serbestleștirme fikrini Amerika'da yerleştirmeye başladığını, Amerika'da 1970'lerde uygulanma şansı bulan bu hareketlerin 1980'lerden itibaren Avrupa'ya da yayıldığı görülmektedir (Sektörel açıdan önemli yeri olan bu tartışmaya istinaden bkz. Fuller, 1983, s.1-17; 78-86; Whitnah, 1998, s.15-40,149; Geddes, 2010, s.26; ek olarak Kuzey Amerika'daki tartışmaların etkili ismi Nelson'un birçok eserinden bazıları için bkz. Nelson 1942; 47;62a; 62b;73; 77; 81). 
değișimler yașarken, havayolu sektöründeki etkisi belirleyici niteliktedir. Serbestleştirmenin bugün sahip olduğumuz uzun ve orta mesafe içerisinde öncü niteliğinde bir havayolu sektörünün ortaya çıkışındaki etkisi son derece önemlidir.

Türk havayolu ulaștırması sektörü dikkate alındığında ise, dünyadaki gelişmelerin ülkeye yansımasında ciddi zorlukların ve gecikmelerin meydana geldiği çalışmamızda ele alınmaktadır. Bu gecikmelerin sebepleri arasında, gelişmekte olan dünyada genellikle rastlanıldığı gibi siyasi boşluk ve politika yapıcı kurumlardaki siyasi istikrar ve güç eksikliği dönemlerini görmek mümkündür. 90’lı yıllara kadar altyapı çalışmalarıyla geçen dönem sonrasında gelmesi gereken açlımların yapılamamış ve bu durumda yeni yüzyıla girilerek çağdaş ulaştırma yapısından uzak kalınmıștır. Bu durum, yeni yüzyıla girdiğimiz döneme ilişkin bir karşılaştırma dahilinde, Şekil 1'de verildiği gibi, karşılaştırmalı olarak çağdaş ulaştırma modellerine genel bir bakışla dahi anlaşılabilir. Bu amaçla çok genel bir karşılaştırmayla Şekil 1'de ortaya koyulan duruma göre, 21. Yüzyılın başına gelindiğinde Türkiye ulaştırma modlarını çeşitlendirmede başarılı olamazken, havayolu ulaştırması da, dünyadaki gelişim düşünüldüğünde, hala başlangıç seviyesinde kalmıştır.

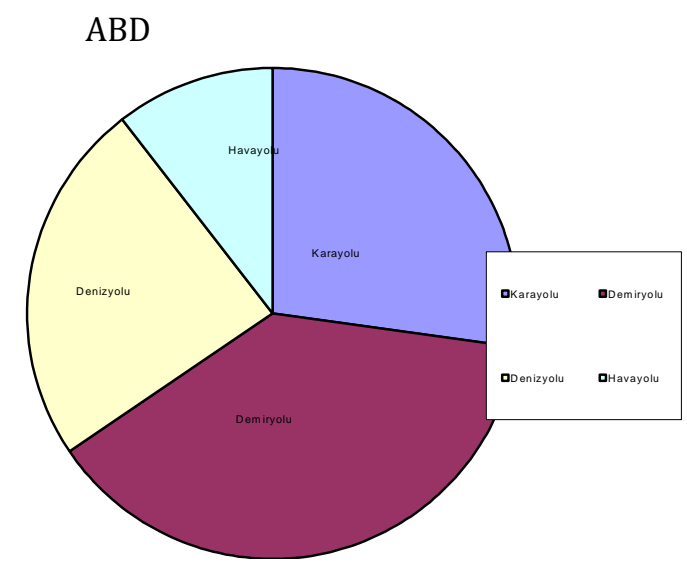

114 | Celal Bayar Üniversitesi Sosyal Bilimler Dergisi - Cilt: 14, Sayı: 2, Haziran 2016 

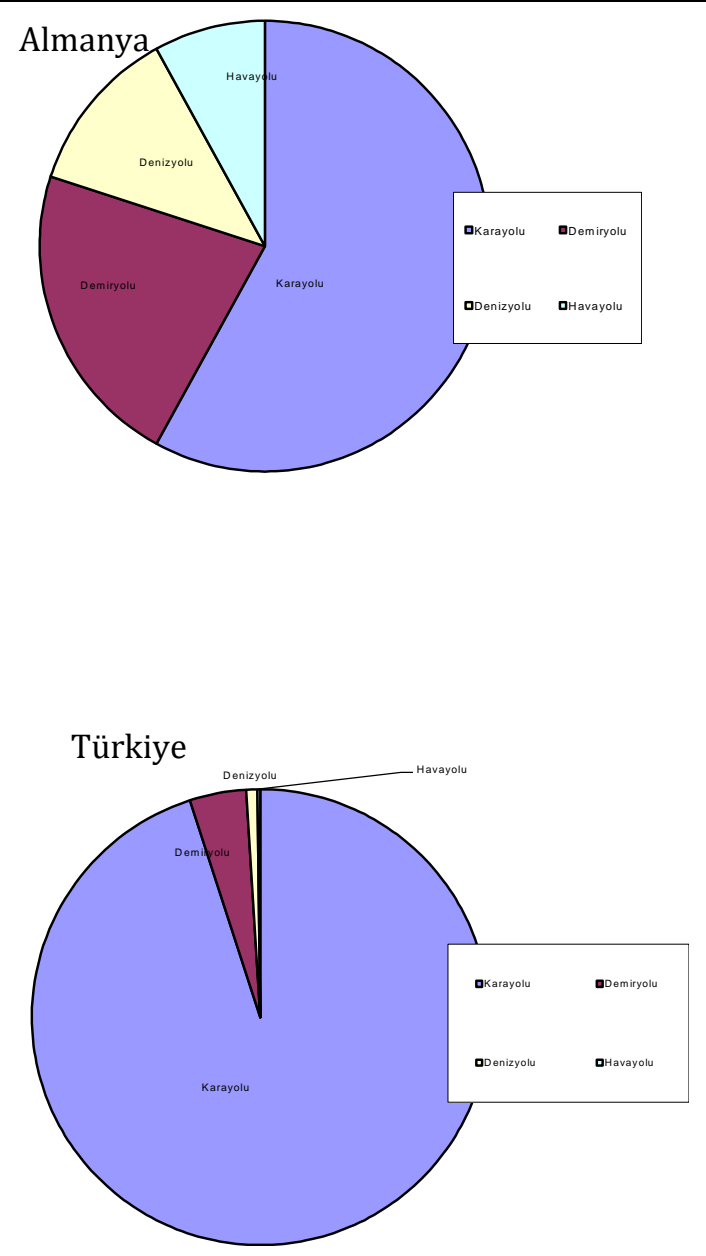

\section{Şekil 1: ABD, Almanya ve Türkiye'de Ulaşım Modlarının} Ulaştırma Yükünü Paylaşımı

(İstatistiki data için kaynak: TVB, 2001-gösterilen kaynak: DPT;

Pampal,1998; Türkiye verileri: DİE, 2003; 2004)

Avrupa'da mesafelere göre taşınan toplam yükün \% 76,5' inin 150 km'den daha kısa mesafelere taşınması söz konusu olduğu için toplam yük içinde \% 76,5 olan karayoluyla taşınma payı, ton-km 
olarak hesaplandığında \% 21,5'e düşebilmektedir. Bu rakkamlar yakın bir değerlendirmenin fotoğrafı nasıl değiștirebileceğini gösterse de, çalışmamızın başlangıç noktasını oluşturan Türk havayolunun değişime geçtiği dönem öncesindeki genel durumu yansıtması açısından Şekil 1'de çizilen çerçeve yeterlidir.

Ulaştırma sektörünün insan ve mal hareketliliğini konu aldığını söylediğimizde sektörünün adını değișim ile birlikte anmak doğal olmaktadır. Bu sebeple yazın içinde sektörel değişimin tespitine yönelik çalışmalar öneemli miktarlardadır. Değişimin ve gelişimin analizine yönelik araçlar ortaya koymak, bu çalışmanın da amacını oluşturmaktadır. Yirminci Yüzyıl içerisinde ulaştırma dünyasında gerçekleșen en önemli iki gelişmeden ikincisi, havayolu ulaştırmasının savaşlar sonrasında doğuşu ve hemen ardından etkileyici büyüme kaydetmesi ve uzun mesafe içinde ulaştırma modları arasında öne çıkabilecek bir yere gelmesidir. Buna karşın, genelde görülen bu başarı hikâyesinin, Türkiye ile birlikte gelişmekte olan dünyaya aksetmesinde bazı sorunlar ve gecikmelerin yaşandığını görmekteyiz.

Çalışmamız 2000'li yılların başlarında, Türkiye'deki sektörel durumu ortaya koymaya ve bu durum üzerinden ekonomik bir çözümlemeye ulaşmaya yönelik bir çalışmadır. Bu dönemin ele alınmasının sebebi, dönemin içerdiği özelliklerden dolayıdır. İlk olarak, yukarıda belirtildiği üzere ulaştırma sektörlerinin değişimle anılması, sektör üzerine yapılan durum tespiti ve karşılaştırma çalışmalarının da kaynağını oluşturmaktadır. Bu sebeple bu dönem karşılaştırmalarına firsat verecek tespit çalışmalarına ihtiyaç vardır. 21. Yüzyıla başarı ile giren dünya havayolu ulaștırması sektörü içinde, yerel sektörel gelişim sürecini incelemek için yüzyll dönemeci önemli bir referans noktası oluşturmaktadır. Bunun dışında, daha da önemli bir neden olarak dönemin Türk havacıllk sektörü için arzettiği önem vurgulanmalıdır. 1980'lerdeki dışa açılma sürecinde, gerçek anlamda havayolu ulaştırması ile tanışan ve yoğun yatırımlara yönelen Türkiye için sektörel atılıma elverişli 90’lı yıllar, ekonomik krizler ve nispeten siyasi otorite boşluğu ve güçsüzlüğü ile geçirilerek önemli bir firsat kaçırılmıştır. 2000'lerin başındaki siyasi değişim süreci sonrasında, uzun süredir, gerek sektörün bizzat kendisinden gelen, gerekse de havacılık otoritesi konumundaki kurumlar aracılığıyla iletilen sektörel tabanın ertelenmiş açılım talepleri sektöre yansımaya başlamış ve bu açılımın etkileri, hızla göstergelerde kendini göstermiştir. Örneğin 2001 yllında 1 olan tarifeli içhat seferleri yapan havayolu işletmesi sayısı, 2002 yılında 1; 
2003 yılında 2 işletmenin açılmasıyla birlikte 2003 yılı sonunda toplam 4'e çlkmıştır. Bu sebeple yeni yüzyıla girdiğimiz 2000'li yılların başındaki bu liberalizasyon döneminin sektörel incelemesinin, havayolu ulaştırması sektörünün gelişimi açısından ve ileride bu gelişimin değerlendirilebilmesi bakımından oldukça anlamlı olduğu düşünülmektedir.

Çalışma konusu dönemin bu özelliklerinin yanında, çalışmamızın sonuçları açısından daha detaylı bir değerlendirmeyle döneme bakıldığında dönemin bazı özellikleri dikkati çekmektedir. 2001 yılında ülke tarihinin en büyük krizlerinden biri yaşanmıştır ve bu sebeple verileri genellikle ekonomik analizlerde istisnai kabul edilir. Buna karşın kriz sonrası oluşturulan ekonomi politikası, daha sonra da devam ettirlmesi açısından önemlidir. 2002 yılı seçim yılıdır fakat kriz sonrasındaki ekonomik yönetimin ertelenmiş sektörel beklentilerin etkisiyle çizdiği liberalleşme çerçevesi uygulamaya girmiştir. 2003 ve 2004 yılından itibaren, bu uygulama hızlanarak devam ettirilmiş, sektördeki büyümenin 2004 yılından itibaren verilere yansıdığı çalışmamızda kendini göstermektedir. Dolayısıyla değişim dönemi öncesi durum değerlendirmesini amaçlayan bu çalışmada dönemin bu özelliklerinin akılda tutulması faydalı olacaktır.

Çalışmanın ikinci bölümünde ele alınan dönem için havayolu sektörünün dünyadaki durumuna yönelik genel bir çerçeve çizilmektedir. Üçüncü bölümde Türk havayolu ulaştırması incelemeye alınmakta ve ayrıca sektörün verimlilikler açısından bir değerlendirmesi yapılmaktadır. Elde edilen sonuçlar dördüncü bölümde değerlendirilirek sonuca bağlanmaktadır.

\section{HAVAYOLU ULAȘTIRMASI SEKTÖRÜ}

Yarım asırdır teknolojik altyapısı hazırlanmış olan havayolu ulaştırması sektörünün 1944 yılında ICAO'nun kuruluşunun ertesi yılında dünyada taşınan 9 milyon yolcu sayısı, 21. yüzyılın başına gelindiğinde yıllık 1.6 milyar yolcuya çıkmıştır. Savaşın bitim yılı için etkileyici olan 9 milyon yolcu hacminin yüzyll sonunda 7 milyarı geçen dünya nüfusunun yaklaşık dörtte biri düzeyindeki 1.6 milyar yolcu sayısı yanında önemini kaybetmektedir5. Yüzyıl başı itibariyle, dünya brüt hasılasının yüzde 4.5'ine tekabül eden 1360 milyar dolarlık ekonomik hacmi üretmektedir. İstihdam sayıları ise geniş ve dar ölçeklerde verilebilir. Dolaylı etkileriyle beraber toplamda

52003 değerleridir ve sadece tarifeli havayollarınca taşınan yolcuları sayılarını içermektedir. Kaynak: ICAO, 2004. 
yaklaşık 27.7 milyonluk istihdamdan, dünyadaki 3000 ticari hava ulaştırma işletmesinde çalışan sayısını dikkate iç çemberi dikkate alırsak yaklaşık 2 milyon kişinin sektördeki istihdamı söz konusudur.6. Havayolu ulaştırmasının geniş tanımı içine tarifeli havayolu işletmelerinin yanısıra tarifesiz havayolları, zirai ilaçlama, özel ulaşım ve turistik ulaşım araçları ve diğer havacılık faaliyetleri dahil edilebilmektedir. Bu şekilde bir çerçeve içinde sektörün en önemli ekonomik faaliyeti olan tarifeli işletmelerin payına bakacak olursak, 2003 yılında taşınan yolcu sayısının 1.6 milyar olduğunu ve taşınan kargo hacminin 34,5 milyon ton düzeyinde olduğunu, sektörün 313 milyar dolar değerinde hasılayı ve 1,6 milyon düzeyinde istihdamı ürettiğini görebiliriz. Geniş tanımı içerisindeki unsurlar ile sektördeki işletmelere mal ve hizmet sağlayan diğer işletmeleri analize katacak olursak, istihdam rakamlarının çok daha büyüyeceğini ifade edebiliriz.

Yüzyılın başına geldiğimizde, havayolu ulaştırmasının uzun ve orta mesafede ulaştırma modları içinde öne çıktığını gözlemleyebilmekteyiz. Yüzyılın başında 188 üyesi bulunan Uluslararası Sivil Havacılık Teşkilatı (ICAO)'nün günümüzdeki üye sayısı 191'dir7. Teşkilat Birleşmiş Milletler örgütünün alt teşkilatı niteliğindedir. Teşkilatın tarifeli seferlere ilişkin verileri (ICAO, 2004b) 2001 yılında taşınan, 538 milyonluk bölümü uluslararası yolcu olan toplamda 1,62 milyar yolcuyu; 1,7 trilyon yolcu-km'si uluslararası trafikten gelen, toplamda 2,9 trilyon yolcu-km'lik çıktı değerini $^{8}$ göstermektedir. Benzer bir şekilde 95 milyar ton-km'si uluslararası olmak üzere toplamda 111 milyar ton-km'lik yük ulaştırmasının çıktısından bahsedilmektedir. Uluslarası havacılık çıktısı, toplam çıtı içinde büyük dilimi temsil ederken bu oranın yük

\footnotetext{
6 Ekonomik rakamlar 1998 yılına referansla verilmektedir: ICAO, 2004. EPATS, Avrupa için benzer rakamları dile getirmektedir (EPATS, 2012).

7 http://www.icao.int. Erişim: 02.07.2015.

8 Havayolu ulaştırmasının ürününü taşınan yolcu ve taşınan yük oluşturmakla beraber, ulaştırma mesafesinin de hesaba katılmasıyla yolcu- $\mathrm{km}$ ve ton-km değerlerine ulaşılır. $\mathrm{Bu}$ amaç doğrultusunda ulaştırma mesafesi, yolcu ve yük miktarıyla çarpılarak yolcu- $k m$ ve ton- $k m$ çıktı değerleri elde edilir. Ulaştırma mesafesini değerlendirmeye katmak vasıtasıyla, örneğin, İstanbul-İzmir ve İstanbulSidney arasındaki uçuşları eşit sayılması gibi bir sonuç önlenmiş olacaktır. Maliyet ve fiyatlar, bire bir olmasa da, mesafe ile artacağından, bu durumda sektörel hasılanın daha doğru olarak yansıması söz konusudur.
} 
ulaştırmasında $\%$ 86'ya $\quad$ kadar $\quad$ (ton-km cinsinden) görülmektedir. ICAO'ya göre (ICAO, 2004b)

Aynı yıllarda dünyada tarifeli hava taşımacılığı yapan işletme sayısı yaklaşık 800, sadece kargo taşımacılığı yapan havayolu işletmesi sayısı 100. Toplamda faaliyet gösteren 3000 ticari havayolu işletmesi içinde bu sayı küçük görünebilirse de, yolcu-km cinsinden bakıldığında ulaştırma ürününün \% 91'inin tarifeli seferlerle üretildiği veridir. Şekil 2' de kıta ve bölgeler ayrımı açısından tarifeli seferler aracılığıyla gerçekleştirilen yolcu ulaştırması payları verilmektedir. Toplam (uluslararası ve yurtiçi trafik dahil) gerçekleşen yolcu-km değerlerinde Kuzey Amerika yaklaşık \% 36 pay ile lider durumdadır. Avrupa ve Asya/Pasifik kıtalarının sırasıyla $\% 28$ ve \% 27'lik paylar ile ikinci ve üçüncü olarak sıralandığını görmekteyiz. Uluslararası taşınan yolcu-km değerlerine göre değerlendirildiğinde Avrupa \% 37 pay ile birinci, Asya/Pasifik ve Kuzey Amerika kıtaları sırasıyla \% 32 ve \% 20 paylar ile ikinci ve üçüncü durumdadır (ICAO, 2004b).

TOPLAM YOLCU ULAŞTIRMASI

(Uluslararası ve Yurtiçi)

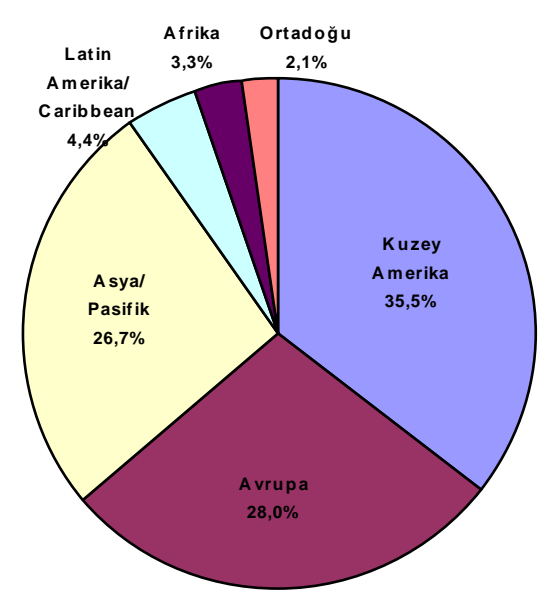

\section{ULUSLARARASI YOLCU} ULAŞTIRMASI

Şekil 2: Toplam ve Uluslararası Yolcu Ulaştırmasının Bölgelere Göre Dağılımı-2001

Kaynak: ICAO, 2004b verilerinden derlenmiştir.

(Gerçekleșen toplam yolcu-km değerlerine göre) 
Şekil 2'de dikkat edilmesi gereken bir nokta olarak, Kuzey Amerika'nın 50 eyaleti içeren 1 ülke durumundayken, Avrupa Birliği içerisindeki 30'a yakın sayıdaki irili ufaklı ülkelerin ayrı ülkeler olarak kabul edilmesinin uluslararası trafik hesaplarını etkilediği unutulmamalıdır. Kuzey Amerika kitasında sadece 3 ülke bulunmasına karşın, Avrupa'daki birçoğu oldukça küçük olan 50’ye yakın ülkeleri arasındaki trafiğin uluslararası olarak sınıflandırılması durumu söz konusudur. Bu faktörler dikkate alındığında, 'büyük üçlü' arasındaki ağırlıkların hemen hemen eșitleneceğini görmek daha kolay olacaktır. Ulaştırma trafiğinin 2 uçlu olduğu düşünüldügünde bunun doğal olduğu düşünülebilir Sonuç olarak, bu üç 'büyük' ulaştırma bölgesinin her iki sınıflandırmaya göre de toplam küresel havayolu faaliyetlerinin \% 90 düzeyindekibir kısmını kapsaması bu yüzyıl başının bir gerçeğidir. Havacılık faaliyetleriyle ekonomik etkinlik arasındaki doğrusal ilişki dikkate alındığında, bu görüntüyü, çağımızın küresel ekonomisi içinde gittikçe belirginleşen üçlü yapısının yüzyıl başındaki öncül göstergelerinden birisi olarak görmemiz doğal olabilir.

\section{YURTIÇCi YOLCU ULAŞTIRMASI}

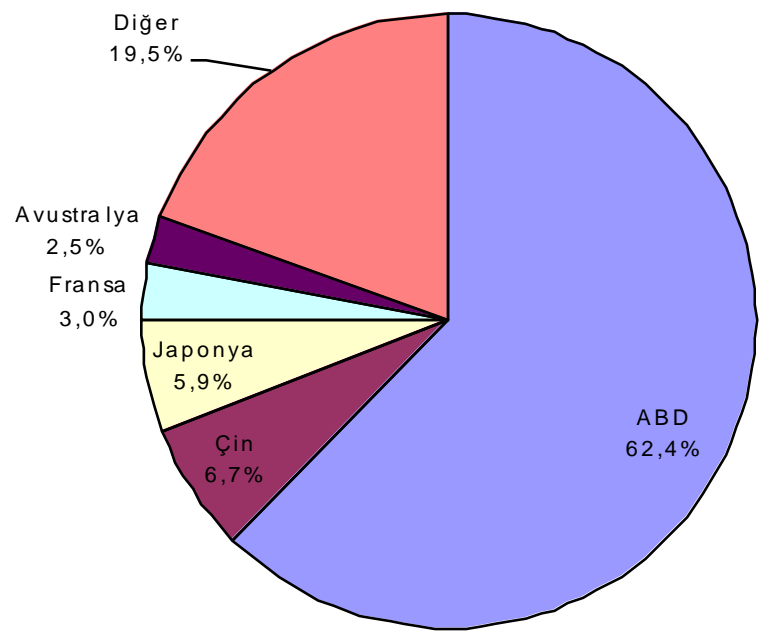

Şekil 3: Yurtiçi Yolcu Ulaştırmasının Ülkelere Göre Dağılımı2001

Kaynak: ICAO, 2004b verilerinden derlenmiştir. (Gerçekleşen toplam yolcu-km değerlerine göre) 
Yurtiçi yolcu ulaştırmasında ABD'nin \% 62,4 oranı ile önemli bir ağırlığı söz konusudur (Şekil 3). Buna karşın, daha önce öne sürülen argüman burada da geçerlidir: Amerika'nın büyük ölçekli eyaletlerinin arasında yurtiçi trafik olarak kaydedilen havayolu faaliyetlerine karşın, Avrupa'nın hememn aynı sayıdaki birçoğu küçük ölçekli ülkeleri arasındaki trafiğin uluslararası trafik olarak sayılması, burada rakamlara yansımaktadır. Avrupa sivil havacılığına baktığımızda, Avrupa'da 1980 sonrasında kaydedilen yıllık ortalama $\%$ 7,4 hava trafiği arttışının her 10-14 yılda bir trafik değerlerinin katlayacağı öngörülmektedir. Avrupa Komisyonu rakamları 2001 yılında Avrupa üzerinde yılda 25.000' in üzerinde uçak uçtuğunu göstermektedir (EC, 2001, s.36) ${ }^{9}$.

ICAO'nun yaptığı hacmine göre dünyanın en büyük 30 havayolu şirketi, 2001'de küresel toplamda tarifeli yolcu ve yük trafiğinde yaklaşık \% 70'i; küresel uluslararası trafikte ise trafiğin \% 73'ünü belirleyen konumda bulunmaktadır. Sözü geçen en büyük 30 havayolu şirketinin kayıtlı olduğu bölgelere göre sayıları 11 Asya/Pasifik bölgesi, 10 Avrupa kıtası, 7 Kuzey Amerika kıtası, 1 Güney Amerika kıtası ve 1 Ortadoğu bölgesi şeklindedir. Bu işletmeler içerisinde Türk işletmesi bulunmamaktadır (ICAO, 2002, s.32-33). Karşılaştırma işletmelere göredeğil de ülkelerin trafik hacimlerine göre yapıldığında, toplamda \% 43'ün sıralamanın en üst 3 ülkesi olan Amerika, Japonya ve İngiltere tarafından sırayla \% 32, $\% 6$ ve \%5'lik oranlar ile; uluslararası havayolu trafiğinde ise $\% 37$ gibi bir oranının sıralamanın en üstteki 4 ülkesi olan Amerika, Birleşik Krallık, Almanya ve Japonya tarafından sırasıyla yüzde 17, yüzde 7 , yüzde 7 ve yüzde 6 'llk oranlarla üretildiği ilgili listede görülebilmektedir (ICAO, 2002, s.34-35). Aynı liste içerisinde, Türkiye, toplam yolcu trafiğine göre 29. sirada yer alarak küresel toplam ulaştırma ürününün \% 0.5 'ini üretmektedir.

\section{TÜRK HAVAYOLU ULAŞTIRMASI}

ICAO'nun verileri ile bakıldığında 2001 yılında, toplamda ve uluslararası tarifeli yolcu trafiği hacimlerine göre yapılan sıralamada, Türkiye sırasıyla 29. ve 30. sırada yer alırken, bu konudaki ürünün yaklaşık olarak ölçüm değerleri sırasıyla 15 ve 12 milyar yolcu-km düzeyindedir (ICAO, 2004b, s.34-35). Bu değerleri, Bölüm 3.1. altında yer alan Tablo 3'deki en büyük havayolu şirketleri ile

9 Değerler, Avrupa Komisyonu'nun 2010 yılına yönelik ulaştırma stratejilerini olușturma amacıyla 2001 senesinde hazırlayarak yüzyıl başında durum tespitinde bulunduğu "Beyaz Belge: karar zamanı" (White Paper: time to decide) çalışmasındandır. 
karşılaştırdı̆̆ımızda, sıralamada 3. olan Delta Airlines șirketinin bile tek başına, Türkiye'nin yolcu-km cinsinden toplam sektör çıktısının 10 katını ürettiğini görebiliriz. Ayrıca 15 milyar yolcu-km olan ülke toplam çıktısı, dünyadaki toplam havayolu ulaştırma ürününün de yaklaşık \% 0.5’i kadar olmaktadır. Türkiye'nin toplam ürünü içerisinde 12 milyar yolcu-km'nin uluslararası uçuşlardan gelmesi, ülkenin bir turizm ülkesi olmasının bir yansımasıdır. Buna karşın, 3 milyar yolcu-km olan yurtiçi uçuşların çıktısının ${ }^{10}$, ABD'nin yurtiçi sektör çıktısının yaklaşık 250'de biri olması ise, yüzyılın başına geldiğimizde havayolu sektörünün yurt içi pazarlara yeteri kadar ulaşamadığını gösterebilir.

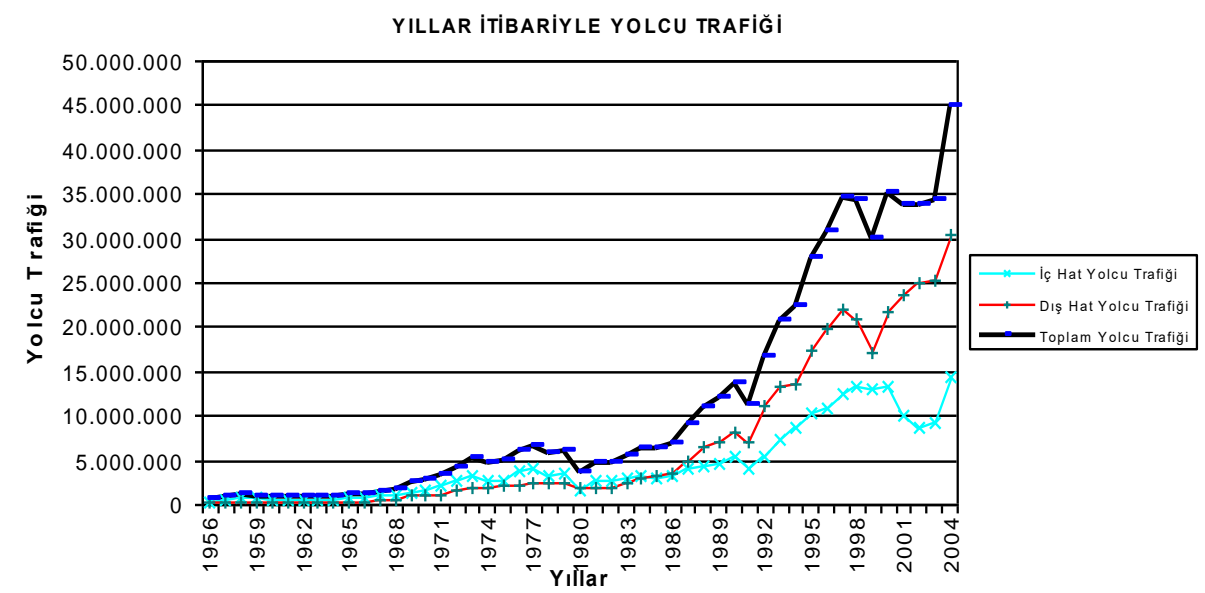

\section{Şekil 4: Yıllar İtibariyle Havaalanlarında Ölçülen Yolcu Trafiği (1956-2004)}

Kaynak: SHGM; DHMİ 2002, 2003, 2004 verileri kullanılmıştır

Havaalanlarındaki yolcu trafiğinin yer aldığı Şekil 4 yardımıyla Türkiye'deki hava ulaştırmasının gelişim çizgisini görmekteyiz. Şekil 4'de yer alan "yolcu trafiği" DHMİ tarafından, havaalanlarında kaydedilen toplam gelen ve giden yolcu sayıları şeklinde tanımlanmaktadır. Şekil 4'de verilen yolcu trafiği değerlerinin 1980, 1991 ve 1998-2000 yıllarındaki duraklama ve daralma dönemleri eşliğinde genellikle yavaş bir tempoda artış eğilimini sürdürdüğü görülmektedir. 1991 sonrası dönemde ise biraz

\footnotetext{
10 Yurtdışı uçuşlarıın aktarmalarının da bu klasmanda sayıldığı göz önüne alınırsa yurt içi pazarın büyüklüğü daha iyi anlaşılacaktır.
} 
daha hızlı bir artışın yer aldığı; 1998 Rusya ve 2001 Türkiye krizleri sonucunda daralma gösteren yolcu trafiğinin 2004 yılından başlayarak çarpıcı bir artış trendine girdiği göze çarpmaktadır. Son tahlilde, 2001 krizi sonrasında hazırlanan ekonomik programa uygun olarak 'Bölgesel Havacılık' politikasının uygulanması kararına bağlı olarak piyasanın yapısal değişim geçirmesi, yurt içi uçuşlarda tarifeli sefer yapan işletme sayısının kademeli olarak 1'den 4'e çıkmasıyla iç piyasanın monopolcü yapısının kırıldığına tanık olunmuş, yolcu trafiğinin \% 58'lik artışıyla birlikte; turizm sektöründeki talep şokunun ve 2001 krizi etkilerinin atlatılması sonucu 2004 yılında dış hat yolcu trafiğinde \% 21 gibi çok ciddi bir artışının altını çizmekte fayda vardır. $\mathrm{Bu}$ noktada belirtmek gerekir ki, Şekil 4'ün geneline yansıyan artış trendi, sıfırdan başlayan ve dünyadaki teknolojik ve ekonomik trendleri izleyen ve turizmle doğrudan bağlantılı olan yerel havayolu ulaştırması için, yine global havayolu sektörünün gelişimiyle karşılaştırıldığında oldukça yetersiz kalmaktadır.

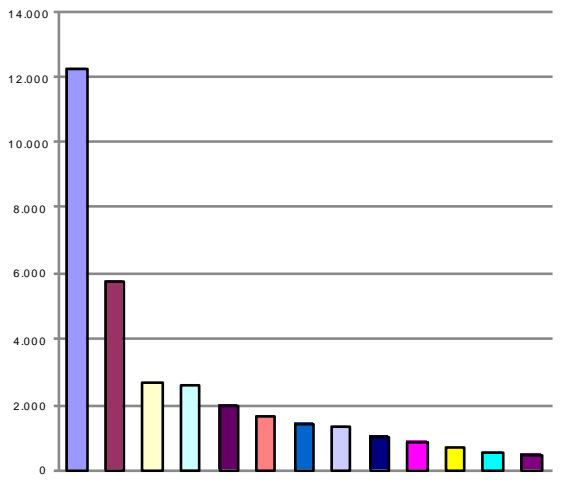

\begin{tabular}{|c|}
\hline 口THY A.O. \\
\hline 口ONUR HAVA TAŞIMACILIK A.S.s. \\
\hline 口FLY HAVAY OLL AR I A,S . \\
\hline 口PEGASUS HAVA TAŞIMACILIK A.Ş. \\
\hline DMNG HAVAYOLLARI T AŞIM ACILIK A.Ş. \\
\hline 口K IBRIS TÜRK HAVAYOLLARI LTD.ŞTİ \\
\hline 口A TL A SJET UL U SLARARA SI H AV A CILIK \\
\hline $\begin{array}{l}\text { A.SS. } \\
\text { 口SUNEX PRESS HAVA YOLLARI A.Ş. }\end{array}$ \\
\hline GFREEB IRD HAVAYOLU TAŞ. ve TİC. A.Ş. \\
\hline
\end{tabular}

\section{Şekil 5: 2004 Yılı Sonunda Türkiye'deki Yolcu Ulaştırmasında Koltuk Kapasiteleri}

Kaynak: SHGM (Tablo 3)

2004 sonunda Türkiye'de 15 ticari havayolu işletmesi faaliyettedir. Bu işletmelerin, yolcu taşımacılığı yapan 13 işletmeden 2 tanesi yalnızca ikişer kargo uçağına sahiptir. Filolarındaki uçak sayıları ve filonun toplam koltuk kapasiteleri dikkate alınarak yapılan bir değerlendirmede en yüksek pay sahibi 2 işletmenin ülkedeki toplam kapasitenin sirasiyla \% 42 ve \% 14'ünü, toplam koltuk kapasitesinin (Şekil 5) ise yine sirasıyla \% 37 ve \% 17'sini oluşturduğu görülmektedir. 
Şekil 6'da yer alan dış hatlar yolcu ulaştırması paylarının, 2002'deki yüzde 49'a karşı 51 durumundan, 2004 senesinde yüzde 52'ye karşı 48 oranına gelinmesiyle hafifçe Türk işletmelerinin lehine gelişmiştir. Bu payın Türk işletmeleri arasındaki ağırlıkları da yine aşağıdaki şekilde verilmektedir.

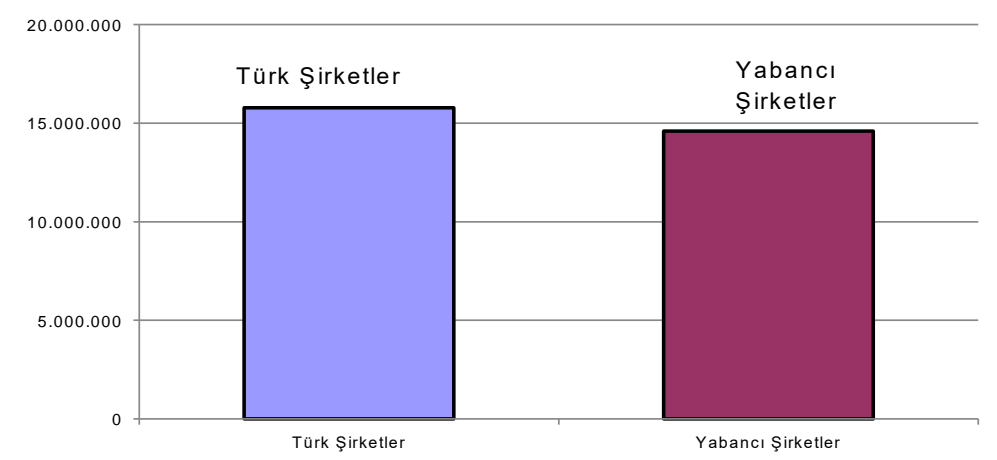

\section{Şekil 6: 2004 Yılı İtibariyle Dıș Hatlar Yolcu Ulaştırmasındaki Durum}

Kaynak: DHMİ, 2004 İstatistik Yıllığının verileri kullanılmıştır

DHMİ İstatistik Yıllığı rakkamlarına göre toplamda dış hat yolcu sayısı 30.361.171 iken, bu sayının 15.771.403 kadarlık bir kısmı Türk işletmelerince taşınan yolcu sayısıdır. Türk işletmelerinin iç hatlarda taşıdığı yolcu sayısı ise yine 2004 yılında 14.427 .969 olmuştur. İç hatlardaki trafiğin \% 93'ü tarifeli seferlerle gerçekleșen trafiktir. Yüzyıl başında iç hat yolcu ulaştırması pastasının çok büyük bir kısmı THY'nce kontrol edilmektedir. Kriz sonrası ekonomik programında yer almasına karşın ancak 2002 yılı sonlarında hayata geçebilen iç hatlarda THY dışındaki işletmelere de lisans verilmesi kararıyla gelen politika değişiminin sonucunda iç hatlar piyasasındaki monopolcü yapının kırılmasına tanık olunmuştur. Şekil 7' de görüldüğü gibi 2002 senesinde pastanın neredeyse tamamı THY kontrolü altındayken, 2003 sonunda gelen değişimin etkisiyle payların değiștiği ancak bu değişim istatistiklere yansımasının 2004 yılıyla birlikte gerçekleşmeye başlaması söz konusudur. 

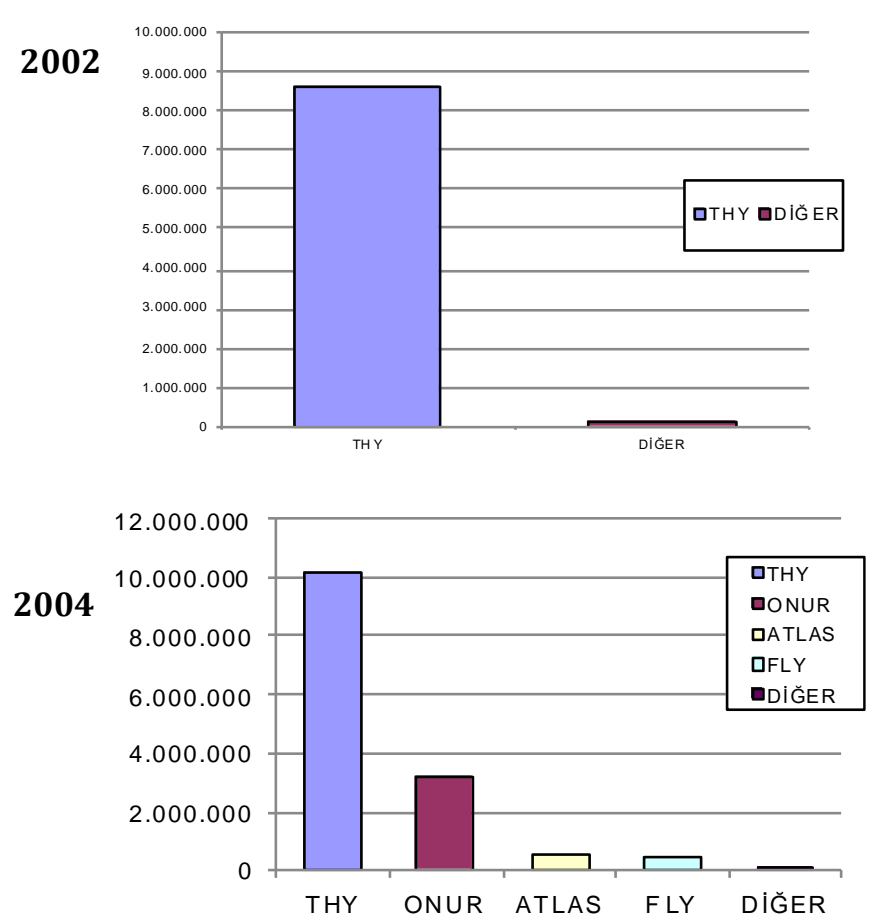

\section{Şekil 7: İç Hat Yolcu Ulaştırması Paylarının Deregülasyon Sonrası Hızlı Gelişimi}

Kaynak: DHMİ, 2004 İstatistik Yıllığı verileri kullanılmıștır

Yüzyll başındaki yolcu trafiğine tarifeli ve tarifesiz seferler ayrımına göre baktı̆̆ımızda iç hatlardaki yolcu trafiğin tamamına yakınının tarifeli seferler kapsamında; dış hatlar yolcu trafiğinin ise çoğunluğunun tarifesiz seferlerle gerçekleştiği görülmektedir. İç hatlar ve diş hatların toplam yolcu trafiği olarak bakıldığında ise tarifeli seferler ağırlığının (2004 rakamlarıyla) \% 53 olarak yansıdığı, sadece dış hatlar yolcu trafiğinde dağılımın \% 65,8 oranında tarifesiz uçuşlardan yana olduğu görülmektedir.

Yolcu trafik değerlerini ayrıca havaalanları istatistiklerinden takip etmek mümkündür. Havaalanları açısından baktığımızda, 1990'larda 'her ile havaalanı' politikaları kapsamında havaalanları sayısında artış yaşandığı ve 2004 yılı sonu itibariyle 64'e ulaştığı, bunun 34 tanesinin DHMİ'nce işletilen havaalanlarından olduğunu görürüz. Şekil 8'de görüldügü üzere 2004 senesi içinde söz konusu havaalanlarındaki yolcu trafiğinin yüzde 90'ının 6 havaalanında; 
yüzde 65'inin ise iki havaalanında (Antalya ve İstanbul Atatürk Havaalanları) gerçekleştiği dikkati çekmektedir.

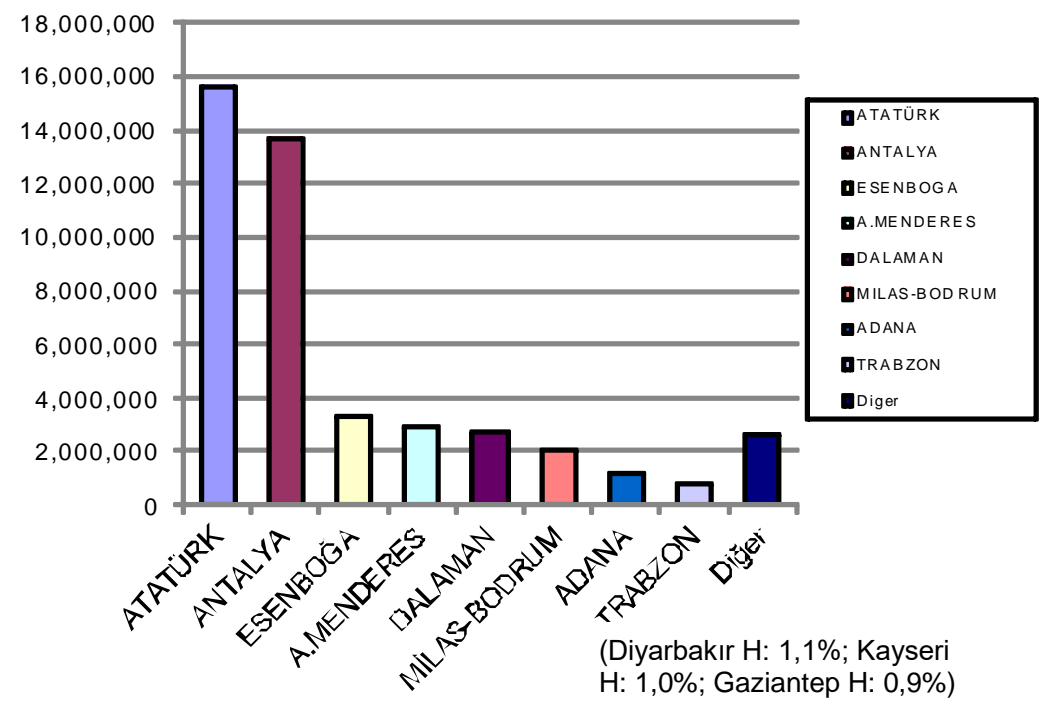

\section{Şekil 8: 2004 İtibariyle Yolcu Trafiğinin Havaalanlarındaki Dağılımı Payları}

Kaynak: DHMİ, 2004 İstatistik Yıllığı

\subsection{Türk Havayolu İşletmelerinin Karşılaştırmalı Girdi Verimlilikleri}

Sektör analizleri açısından performans kriterleri günümüzde önemli bir yerdedir. Bu anlamda performans kriterlerinden bir tanesi de faktör verimlilikleridir. $\mathrm{Bu}$ sebeple aşağıda Türk havayolu işletmelerinin girdi verimlilikleri ele alınarak dünyanın en büyükleri listesindeki işletmeler ile karşılaştırılmaktadır. Girdi verimlilikleri hesapları 2002-2004 yılları arasındaki yaklaşık 3 yıllık dönemin aylık verilerini kapsayan bir veri seti kullanılarak gerçekleştirilmiştir. Tablo 1'de yer alan 8 işletme için aylık ortalama girdi ve çıktı değerleri hesaplanmıș, daha sonra bu değerler yardımıyla yıllık ortalama girdi verimlilikleri elde edilmiştir. 33 ay uzunluğundaki veri seti ve işletmelerin farklı uzunlukta serileri mevcut olduğundan öncelikle aylık ortalamalar ardından yıllık ortalamaların hesaplanması yerine getirilmiştir. 


\section{Tablo 1: Havayolu İşletmelerinin Ortalama Girdi ve Çıktı Değerleri İle Ortalama Girdi Verimlilikleri* (Veri seti: 2002/01 - 2004/09, 8 işletme)}

\begin{tabular}{|c|c|c|c|c|c|c|c|}
\hline & A & B & C & D & $\frac{A \times 12}{D}$ & $\frac{A \times 12}{B}$ & $\frac{A \times 12}{C \times 12}$ \\
\hline İşletme & $\begin{array}{l}\text { ort.yolcu-k } \\
\qquad \begin{array}{c}\text { (000) } \\
\text {-aylik- }\end{array}\end{array}$ & $\begin{array}{l}\text { ort.koltuk } \\
\text { kapasitesi }\end{array}$ & $\begin{array}{l}\text { akıt sarfiyatı } \\
\text {-aylık- }\end{array}$ & $\begin{array}{l}\text { ort.persone } \\
\text { mevcudu }\end{array}$ & $\begin{array}{l}\text { prt.işgüc } \\
\text { verml. } \\
\text { (000) } \\
\text {-yılllk- }\end{array}$ & $\begin{array}{r}\text { üort.koltuk } v e \\
\text { (sermaye ve } \\
(000) \\
\text {-yılllk- }\end{array}$ & $\begin{array}{l}\text { ort.yakıt } \\
\text { verimlilği } \\
\text { (000) } \\
\text {-yıllık- }\end{array}$ \\
\hline THY & 1419479 & 10725 & 77729146 & 10707 & 1591 & 1588 & 0,2191 \\
\hline FLY & 623884 & 1676 & 6733311 & 396 & 18885 & 4467 & 1,1119 \\
\hline ONUR & 510886 & 4051 & 19784777 & 911 & 6729 & 1513 & 0,3099 \\
\hline SKY & 49127 & 710 & 3840542 & 163 & 3615 & 830 & 0,1535 \\
\hline PEGASUS & 365569 & 2560 & 11045158 & 657 & 6679 & 1714 & 0,3972 \\
\hline$\underline{\text { SUN }}$ & 233509 & 1332 & 6964208 & 419 & 6690 & 2104 & 0,4024 \\
\hline MNG & 158896 & 1205 & 6337086 & 765 & 2494 & 1582 & 0,3009 \\
\hline FREEBIR] & 72521 & 722 & 3374100 & 164 & 5311 & 1205 & 0,2579 \\
\hline
\end{tabular}

*: Kaynak: SHGM; 'Havayolu İşletmeleri Bilgileri' soru formundan derlenmiştir (verimlilik hesaplamaları yazara aittir)

Tablo 1'de hesapladığımız Türk havayollarının değerlerinin küresel ölçekte en büyük on işletmenin verimlilikleriyle karşılaştırılması amacıyla, Tablo 3'de en büyük ilk on havayolları işletmesinin 2002 ve 2003 yıllarındaki değerleri aracılığıyla girdi verimlilikleri hesaplanmıştır. Ek olarak işgücü verimliliklerinde dünya ortalaması hesabı Tablo 2'de gerçekleștirilmiştir. 2001 değerleriyle hesaplanan küresel değerlerin ICAO tarafından tahmin ve yaklaşımlar aracılığıyla hesaplandığı ve çoğu zaman düzeltmelere başvurulduğu göz önünde bulundurularak düzey olarak dikkate alınması yerinde olacaktır. Çekincelerine karşın en geniş rezervuarı temsil eden dünya ortalaması değerlerinin karşılaştırmalar açısından değerli bir veri olduğu kabul edilebilir.

Tablo 2: İşgücü Verimliliğinin Dünya Ortalaması Hesaplaması, 2001

\begin{tabular}{c|c|c|c|c}
\hline & yıl & $\begin{array}{c}\text { yolcu-km } \\
(000)\end{array}$ & Personel & $\begin{array}{c}\text { işgücü verimliliği } \\
\text { (000) }\end{array}$ \\
\hline $\begin{array}{c}\text { Dünya Havayolu Ulaştırması Sektörü } \\
\text { (tarifeli+tarifesiz) }\end{array}$ & 2001 & 2.930 .370 .000 & 1.718 .000 & 1724 \\
\hline
\end{tabular}

Kaynak (sayısal değerler için): ICAO, 2004b (verimlilik hesaplaması hariç) 
Tablo 1 ve Tablo 2 üzerinden yapacağımız ilk incelemeler göstermektedir ki, yüzyıl başında dünya ortalaması altındaki 1591 verimlilik değerine sahip THY dışında ortalamanın altında olan başka bir Türk işletmesi yoktur. Fakat, personel açısından diğer işletmelerin THY'ye göre oldukça küçük ölçekte olmaları önemli bir farklılıktır. Tablo 3'de yer verilen dünyanın en büyük ilk on işletmesinin değerleri, THY'nin değerleriyle daha mukayese kabul eder değerlerdir. THY'nin bu listede, işücü verimliliği olarak yaklaşabildiği tek havayolu işletmesi, kendisinden 6 kat daha büyüklükte istihdam seviyesine sahip ve işgücü verimliliğinde dünya ortalaması altında kalan tek büyük havayolu (bkz. Tablo 3) olan Air France idir. Diğer Türk işletmelerin oldukça büyük işgücü verimlilikleri söz konusudur. Hatta, birçok Türk işletmesi, işgücü verimliliğinin en ileri ülkelerinden Japonya'nın havayolu Jal'ın, diğer top 10 işletmelerine göre çok üst düzey olan 4225 değerinin dahi üzerinde değerlerdir. Bu sonuçlarda, ölçek farkı dışında, söz konusu işletmelerin sıklıkla başvurduğu kiralama yöntemlerinin istatistiklere yansımamasının da olduğu unutulmamalıdır.

Fly havayollarının üç verimlilik değerinde de en yüksek olduğu görülmektedir. Bununla beraber ilk on işletmelerinin verileriyle karşılaştırıldığında Fly işletmesinin değerlerinin sıradışı olduğu görünmektedir. Bu durum yakından incelendiğinde Fly işletmesinin çok düşük istihdam ve koltuk (öz kaynaklarındaki) değerleri göze çarpmaktadır. Buna karşın sıkça rastlanılan kiralama yöntemlerinin istatistiklere yansımadığ ve nispeten yeni sayılan işletmelerden bazılarının istatistiklerindeki büyük hata paylarına tekrar dikkat çekmek gerekir. Sektör çıktısı yolcu-km veya ton-km olarak olmasa da, trafik büyüklükleriyle DHMİ tarafından ölçüldüğü için, kiralama metoduyla gelen kapasitenin sayılara yansımamasının verimlilik hesaplarında yukarı yönlü sapma yaratacağını hesaplamak zor olmayacaktır.

Analiz dönemi içinde, Türk işletmeleri arasında koltuk ve yakıt verimliliklerinde en düşük işletmenin Sky olduğu görülmektedir. Tablo 3'de yer verilen en büyük küresel 10 işletmenin koltuk sayısı cinsinden hesaplanan sermaye verimliliklerinin ${ }^{11}$ dar bir değer aralığında değiştiği dikkati çekmektedir. Bu anlamda Tablo 3'deki faktör verimliliği hesaplarının birbiriyle tutarlı ve

\footnotetext{
${ }^{11}$ Havayolu işletmeleri için sermaye verimliliği hesaplarında parasal değerler yerine, sermayeyi uçak veya koltuk miktarı gibi fiziksel büyüklüklerle temsil etmek mümkündür.
} 
karşılaştırmalar için uygun bir taban sunduğunu söyleyebiliriz. İlk bakışta Türk işletmelerin yarısının bu aralık içinde olduğu görülmesine karşın, bütün içinde değerlendirildiğinde oldukça farklı değerlerin olması, sermaye verimlilik değerlerinde sapma olduğu şüphesini güçlendirir. Hata payını göz önünde bulundurmaya devam ederek bir yorum yapmaya çalışırsak, Tablo 1'deki Türk işletmelerin genel olarak sermaye verimliliğinde rekabete çok hazır olmadığını söyleyebiliriz. Kapasite arttıkça verimlilikleri yüksek oranlarda tutmak için yönetim ve koordinasyon konularında daha yüksek başarıların gerekli olduğu düşünülürse, nispeten küçük ölçekli THY dışındaki Türk işletmelerin daha yüksek verimliliklere sahip olmasının normal olacağını söyleyebiliriz. Buna karşın, Türk havayolu ulaştırması sektörünün açılım dönemi başlangıcında, global ölçekteki rekabete hazır olan işletmeleri (istatistiki sapmaya rağmen) Fly, Sun ve Pegasus olarak vermek mümkündür. THY diğer işletmelerden oldukça fazla personel yapısıyla personel verimliliğinde oldukça geriye düşmüş gözükmektedir. Buna karşın, bu dezavantajına rağmen iç piyasadaki koltuk verimliliği yarışında 'ben de varım' diyebilmesi, hatta Onur, MNG gibi işletmelerin önünde yer alabilmesi, işletmenin rekabetçi özelliklere sahip olduğunu göstermektedir. THY için son tahlilde, işletmenin personel verimliliğinde dünya ortalamasının altında kalması, önemli bir uyarı sinyali olarak dikkate alınarak gerekli adımların atılması halinde, işletmenin koltuk (veya sermaye) verimliliğinde dünyadaki örneklerinden kopmamayı başarmış ve iç piyasada rekabete hazır yapısıyla önemli başarılara ulaşabileceği şeklinde değerlendirilebilir.

Diğer bir verimlilik değeri olan yakıt verimliliğindeki değerlere bakıldığında Fly dışındaki işletmelerin değerlerinin birbirine yakın olduğunu görmekteyiz (Tablo 1). Yakıt verimliliği değerlerine etki eden en önemli faktörler arasında teknoloji ve ortalama bacak uzunluğu $\left(\mathrm{ASL}^{12}\right)$ bulunmaktadır ${ }^{13}$. Yakıt verimlilikleri ele alındığında, teknolojik farkların çok yüksek olmayacağı göz önüne alınarak yakıt verimliliği değerlerinin daha dar aralıkta bulunacağının bekleneceği değerlendirilebilir. Buna karşın Tablo 3'de yer alan en büyük küresel 10 havayolu işletmesinin yakıt verimliliği değerlerinin mevcut olmaması karşılaştırma imkanını elimizden alsa dahi Fly havayollarının oldukça sıradışı değeri, daha

12 Ortalama Bacak Uzunluğu (Average Stage Length): Aktarma süreleri dışındaki uçuşların ortalama uzunluğudur.

13 İniş ve özellikle kalkışlar normalden daha fazla güç harcandığı uçuş safhalarıdır. Bu sebeple ASL yakıt verimliliğini etkiler. 
önce işgücü verimliliği üzerine değerlendirilen istatistiki sapma şüphelerini burada daha da güçlendirmektedir. Bu değerlendirmeler aracılı̆̆ıla Fly havayolunun değerlerindeki hata payının yüksek olduğu ve hatta değerlendirme dışı tutulması gerektiği sonucuna varılabilir.

Tablo 3: Dünyanın En Büyük İlk 10 Havayolu İşletmesinin Girdi Verimlilikleri, 2002-2003

\begin{tabular}{|c|c|c|c|c|c|c|}
\hline & yil & $\begin{array}{c}\text { yolcu-km } \\
(000)\end{array}$ & personel & koltuk $^{2}$ & \begin{tabular}{|l} 
işgücü \\
verimliliği \\
$(000)$
\end{tabular} & $\mid \begin{array}{l}\text { koltuk } \\
\text { verimliliği } \\
(000)\end{array}$ \\
\hline \multirow{2}{*}{ United } & 2002 & 176.773 .979 & 79.000 & 100.223 & 2238 & 1764 \\
\hline & 2003 & 167.183 .939 & 64.500 & 97.511 & 2592 & 1715 \\
\hline \multirow{2}{*}{ American } & 2002 & 196.124 .411 & 102.900 & 117.622 & 1906 & 1667 \\
\hline & 2003 & 193.143 .788 & 86.800 & 126.662 & 2225 & 1525 \\
\hline \multirow{2}{*}{ Delta } & 2002 & 152.068 .960 & 67.800 & 108.992 & 2243 & 1395 \\
\hline & 2003 & 143.543 .664 & 61.000 & 96.154 & 2353 & 1493 \\
\hline \multirow{2}{*}{ Northwest } & 2002 & 116.338 .560 & 45.600 & 70.139 & 2551 & 1659 \\
\hline & 2003 & 110.209.387 & 39.600 & 67.469 & 2783 & 1633 \\
\hline \multirow{2}{*}{ British Airways } & 2002 & 96.892 .180 & 51.350 & 56.888 & 1887 & 1703 \\
\hline & 2003 & 99.702 .421 & 48.400 & 53.464 & 2060 & 1865 \\
\hline \multirow{2}{*}{ Air France } & 2002 & 96.798 .737 & 60.015 & 48.930 & 1613 & 1978 \\
\hline & 2003 & 97.679 .677 & 60.032 & 43.127 & 1627 & 2265 \\
\hline \multirow{2}{*}{ Continental } & 2002 & 92.792 .217 & 39.500 & 51.255 & 2349 & 1810 \\
\hline & 2003 & 91.886 .634 & 38.430 & 51.655 & 2391 & 1779 \\
\hline \multirow{2}{*}{ Lufthansa } & 2002 & 93.678 .029 & 26.960 & 49.806 & 3475 & 1881 \\
\hline & 2003 & 96.728 .312 & 26.750 & 48.890 & 3616 & 1978 \\
\hline \multirow{2}{*}{ Jal } & 2002 & 83.575 .693 & 19.780 & 44.622 & 4225 & 1873 \\
\hline & 2003 & 76.249 .554 & 5 & L & I & 1 \\
\hline \multirow{2}{*}{ US Airways } & 2002 & 64.488 .186 & 33.600 & 44.933 & 1919 & 1435 \\
\hline & 2003 & 60.708 .572 & 27.200 & 41.250 & 2232 & 1472 \\
\hline
\end{tabular}

Kaynak: ICAO; http://icaodata.com, http://icaosec.icao.int (verimlilik hesaplamalar yazara aittir)

1: ICAO'nun yolcu-km cinsinden çıktı değerlerine göre hazırladığı listeden alınmış 2001 yılı sıralamasıdır.

2: Yıl içi ortalamalarıdır

130 | Celal Bayar Üniversitesi Sosyal Bilimler Dergisi - Cilt: 14, Sayı: 2, Haziran 2016 
Burada belirtmek gerekir ki çalışmamızda ulaştığımız daha genel ölçekli karşılaştırmalar bir yana, detaylı birebir karşılaştırmalarda bulunmak için benzer nitelikli işletmelerin karşılaştırılmasının (ürün kalitesini de dikkate alacak şekilde) esas alınması gerekir. Örneğin, Amerikan işletmelerinin trafik değerleri çoğunlukla yurtiçinde, Avrupa ve Asya şirketlerinin trafik değerlerinin ise uluslararası seferlerde ortaya çıktığı dikkate alınmalıdır. Bu amaçla, ürün kalitesi ve ölçek gibi özellikler de detaylı karşılaştırmalarda ölçüt olarak kullanılabilir. Genel bir sektör değerlendirmesini amaçlayan çalışmamız için, işletme bazında daha detaylı bir performans değerlendirmesine girilmesine doğal olarak gerek görülmemektedir.

\section{DEĞERLENDİRME ve SONUÇ}

Kaynağını insan hareketliliğinden alan ulaştırma olgusundan bahsederken, ulaştırma setörünün doğuşu ve ardından önemli dönüm noktalarını ardında bırakarak günümüzdeki şekline dönüşümü sürecini son iki yüzyıl ile sınırlayabileceğimizi dile getirebiliriz. Değişim sürecinin ilk önemli başarısı olan yirminci yüzyıldaki demiryolu ulaştırmasının başarı hikâyesinin başka bir benzerini yirmibirinci yüzyıl içinde otomotiv ve uçak teknolojilerinin aracılığıyla karayolu ve havayolu ulaştırmasının yakaladığı ifade edilebilir. 1960 sonrasında, yeni yüzyılınbaşına kadar gerek trafik değerleriyle gerekse ekonomik açıdan sınırlarını 30-40 kat büyütebilmeyi başaran bir havayolu ulaştırması söz konusudur.

Günümüzde ekonomik büyüklük anlamında öne çıkan Amerika, Avrupa ve Asya bölgelerindeki havayolu trafiğinin toplam trafik içinde de \% 90 payı almasının, ulaştırma ve ekonomi arasındaki girift ilişkinin derecesi üzerine fikir verebilmektedir. Ton$\mathrm{km}$ cinsinden ölçümlerde de toplam yolcu ve toplam yük trafiğinde kendi başına tüm dünya trafiğinin yüzde 32'yle üçte birini oluşturması ve ulaştırma çıktısının hacmine göre en büyük 10 havayolu işletmesi arasında 6'sının, en büyük 5 içinde ise 4'ünün Amerikan havayolu işletmelerinden olması, yirmibirinci yüzyılın başına gelindiğinde sektör liderliğini ABD'nin aldığını göstermektedir. Ekonomik faaliyetlerle ilişkisini incelediğimiz bir havayolu ulaştırması sektörü için, dünyanın en büyük ekonomisi olan Amerikanın sektör lideri olması şaşırtıcı değildir.

Uzun mesafe insan ulaştırmasında öne çıkan bir havayolu ulaştırması sektörü için yurtiçi ulaştırma faaliyetlerinin yüzde 41 oranına ulaşabilmesi şaşırtıcı görülebilirse de, bu payın yaklaşık üçte ikisini tek başına, dünyanın en büyük ekonomisi olarak Amerika'nın 
sağladı̆̆ı unutulmamalıdır. Bu noktada, Amerika'nın büyük ölçekli eyaletleri arasındaki uçuşlar ile Avrupa'nın küçük ölçekli ülkeleri arasındaki uçuşların ayrı sınıflandırmalar içerisinde olmasının çok anlamlı olmadığı tespit edilmelidir.

Yüzyıl başında, tarifesiz uçuşların on katı gibi bir değere ulaşan tarifeli havayolu ulaştırması, sistemin özünü oluşturur gözükmektedir. Öyleki, dünyanın en büyük havayolu işletmelerinin yolcu-km cinsinden sektör çıktıları, tüm dünya havayolu piyasasının \% 6-7'si değerlerine ulaşabilmektedir. Listedeki 10 büyük havayolu işletmesi beraber ele alındığında, tüm çıktının \% 40'ını oluştururken; dünyadaki yüzlerce işletme arasından dünyanın en büyük 3 havayolu işletmesi birlikte, dünya sektör çlktısının \% 18'ini üretmektedir. Bu durum, geçen yüzyıl havayolu ulaştırması sektörünün yaşadığı önemli başarının kilit noktası olarak, havayolu işletmelerinin rolünü ortaya koymaktadır.

Yüzyıl başında, dünya ekonomisinin yüzde 4.5 'ini oluşturan önemli bir sektörü haline gelen havayolu ulaştırması sektöründeki gelişme ve devinim, Türk havayolu sektöründe görülememektedir. Yüzyıl başına gelindiğinde, 90 'lı yıllarda turizm sektörünün gelişmesine bağlı olarak özellikle yurtdışı uçuşların süreklediği nispeten küçük ölçekli artışların çok anlamlı olmadığı, yurtiçi uçuş değerlerinden görülebilmektedir. 2001 krizi ardından konsolide olan siyasi otoritenin de etkisiyle, sektörün uzun süredir beklediği açılımların sektöre yansıması ertesinde, yurtiçinde tarifeli sefer yapan havayolu işletmesi sayısı 1'den, 2004'te 4'e çıkmıştır. Bunun dışında, bölgesel havacılık açılımı ile sektörde başlayan hızlı değişim, ancak 2004 yılından itibaren istatistiklere yansımaya başlamaktadır.

Sektörün sadece THY üzerine dayanan, aynı zamanda turizm sektöründen güç alan yapısı, dünyadaki gelişmenin çok uzağında ve çok kısıtlı bir düzeyde kalmıştır. Böyle bir gecikmenin nedenleri arasında, 80'li yatırım yıllarının ardından dünyadaki gelişmeleri takiben 90'lı yılların açılımlara müsait ortamının siyasi güçsüzlük dönemleri nedeniyle değerlendirilememesi olarak görülebilir. Turizm bölgeleri dışındaki havaalanı faliyetlerinin yüzyıl başında neredeyse yok seviyesinde olmasi, havayolu faaliyetlerinin seviyesine yönelik önemli bir göstergedir. Nitekim tüm yolcu trafiğinin 2/3'ü İstanbul ve Antalya havaalanlarında; yine tüm yolcu trafiğinin \% 90' gerçekleşmektedir. Bu 6 havaalanı içerisinde turizm bölgesi olmayan tek havaalanı olan başkent Ankara'nın Esenboğa havaalanının payı, 
2004'te açılım sonrasında dahi yüzde 90 içerisinde ancak yüzde 7 olmaktadır.

Havayolu ulaştırması sektörünün dünyadaki göz alıcı başarısı altında sektörel Pazar düzenlemelerinin önünü açtığı rekabetçi ortamın payı önemli görülmektedir. Aynı neden, yine Türkiye havayolu ulaştırmasının dünyadaki gelişmeleri takip etmekte neden gecikmeler yaşadığının da kilit noktası olmaktadır. Türkiye'de yaşanan siyasi gelişmeler, sektörün talep ettiği, pazarın serbestleştirme düzenlemeleriyle önünün açılması yönünde gecikmeler yaşanmasına neden olmuştur.

Havayolu ulaştırmasının dünyadaki sektörel başarısının altında düzenlemelerle desteklenen pazarın rekabetçi yapısı tespit edilmesiyle beraber, rekabetçi yapıya yönelik önemli bir gösterge olan verimliliklere yönelik olarak çalışmamızda uygulanan analizin önemli sonuçlar verdiği görülmektedir. Sektörde öne çıkan aktörler olarak en büyük havayolu işletmeleri listesindeki havayolu işletmelerinin girdi verimlilikleri hesaplandığında, işletmelerin verimlilik değerlerinin birbirine yakın olduğu görülmektedir. Buna göre, tabloda hesaplanan düzey değerleri cinsinden, işgücü verimliliğinde, Air France dışında, 2000'li değerlerin üzerine, koltuk verimliliğinde ise 1500-2000 arası değerlere ulaşıldığı görülmektedir. Sıralamadaki ilk 10 işletmenin hepsinin de işgücü verimliliğinde dünya ortalamasının üzerine çıkmış olması dikkat çekicidir. Bu değerlerin, çalışmamızda hesaplanan iç piyasadaki işletmelerin verimlilik değerleriyle karşılaştırılması, sektörel açılımın başlangıç noktasındaki Türk işletmelerin durumuna ilişkin önemli bilgiler ortaya koyabilmektedir. Yüzyıl başında iç pazarın tamamına yakın kısmına hâkim olan THY'nin, açılımların başlangıcında düşük verimlilik değerleriyle rekabete çok hazır olmadığı görülmektedir. THY verimlilik değerlerinde, kendisinden personel ve koltuk kapasitesi açısından 3-10 kat, sektörel çlktı olarak ise 40-130 kat büyük olan, dünyanın ilk 10 işletmesinin gerisinde kalmıştır. Ayrıca, personel verimliliğinde dünya ortalamasının da gerisinde olması önemli bir gösterge olarak değerlendirilmektedir. Ulaştırma hizmetlerinde devasa büyüklüklere ulaşan havayolu işletmelerinin, küçük ölçekteki bir işletmeye göre, verimlilik değerlerini korumaları, ortaya çıkan ek koordinasyon ve yönetim ihtiyaçlarının en iyi şekilde oluşturulabilinmesine bağlıdır. Buna karşın, sıralamada ilk 10'da yer alarak rekabette en başarılı sayabileceğimiz işletmelerin hepsinin yüksek verimlilik değerlerini yakalaması ve özellikle hepsinin de dünya ortalamasının üzerinde olması, sektörün rekabetçi yapısına 
yönelik çok önemli bir göstergenin tespiti olarak değerlendirilmektedir.

Türk işletmelere yönelik değerlendirme içerisinde, diğer işletmelerde işgücü verimlilikleri olarak THY ile kıyaslandığında genellikle oldukça yüksek değerler bulunmuştur. Koltuk verimlikleri ise değişkenlik göstermektedir. Burada hemen belirtmek gerekir ki, sektörde özellikle diğer işletmelerin sıklıkla kullandığı kiralama uygulamalarının istatistiklere yansımaması, büyük sapmalara yol açtığı için, diğer işletmelerin değerleri çok fazla dikkate alınamamaktadır. Buna karşın oturmuş yöntemleri ve güvenilir verileri ile THY'ye yönelik hesaplamalar bu son değerlendirmenin dışındadır ve Türk hava ulaştırmasının gelişimine yönelik burada varılan değerlendirmelerin en önemli dayanak noktalarından biri durumundadır.

\section{KAYNAKLAR}

DHMİ, (2002). Ístatistik Yıllığı 2002, Devlet Hava Meydanları İşletmesi, Ankara

DHMİ, (2003). Ístatistik Yıllığı 2003, Devlet Hava Meydanları İşletmesi, Ankara

DHMİ, (2004). Ístatistik Yıllığı 2004, Devlet Hava Meydanları İşletmesi, Ankara

DİE, (2003a). İstatistik Göstergeler1923-2002, DİE, Ankara.

DİE, (2003b). Havayolu Taşımacılığı İstatistikleri 2001, DİE, Ankara.

DİE, (2004). Ulaștırma İstatistikleri Özeti-2002, DİE, Ankara.

DPT (2001). VIII.Kalkınma Planı, ÖIK Raporu. DPT, Ankara.

EPATS-European Personal Air Transportation System (2012). Evaluation of the air transport efficiency definitions and their impact on the European Personal Air Transportation System. http://www.epats.eu/files/papers/rohacs_epats.pdf. Erişim tarihi: 05/04/2012.

EC, (2001). White Paper: Time to Decide, European Comission, Office for Official Publications of the European Communities, Luxembourg.

GEDDES, R.R. (2010). The Road to Renewal: Private investment in US Transportation Infrastructure. American Enterprise Institute, Washington, DC.

FULLER, J.W. (1983). Regulation and Competition in Transportation. Center for Transportation Studies, University of British Columbia. Vancouver, Canada. 
HARVEY, D. (1990), The Condition of Postmodernity: An enquiry into the origin of cultural change. Blackwell, Massachussets, USA.

ICAO, (2004a). "Key trends highligth enduring success of the world air transport industry", ICAO Journal, 59(8), 4-6, 23.

ICAO, (2004b). The World of Civil Aviation, 2001-2004, Circular 291-AT/123 (11/02 E/P1/1400), ICAO HQ, Montreal

NELSON, J.C. (1942). "New Concepts in Transportation Regulation". In Transportation and National Policy (197-237). US Government Printing Office. Washington, DC.

NELSON, J.C. (1947). "Some Problems of Postwar Air Transportation". American Economic Review. 2 (37), 492-97.

NELSON, J.C. (1962a). "The Pricing of Highway, Waterways and Airways Facilities". American Economic Review. 2 (52), 15-22; 426-33.

NELSON, J.C. (1962b). “Government's Role Toward Transportation". Transportation Journal. 4 (1), 15-22.

NELSON, J.C. (1973). "A Critic of Governmental Intervention in Transport". In Joseph S. De Salvo (ed.) Perspectives on Regional Transportation Planning. Lexington Books, Lexington. Massachussets.

NELSON, J.C. ve Heaver, T.D. (1977). Railway Pricing Under Commercial Freedom: The Canadian Experience. Center for Transportation Studies, University of British Columbia. Vancouver, Canada.

NELSON, J.C. (1981). "British Deregulation and US Transport Policy". In Kenneth D. Boyer and William G. Sheherd (eds.) Economic Regulation: Essays in Honor of James R. Nelson. Michigan State University. East Lansing, Michigan.

PAMPAL, S. (1998). "Ülkemizde Trafik ve Trafik Kazaları", Trafik Dergisi, Yaz Özel Sayısı , 1-3.

TUTULMAZ, 0. (2013). "Ulaştırma modları içerisinde bir başarı hikâyesi: 21. Yüzyılın başında havayolu ulaştırması sektörü". Türkiye Sosyal Araştırmalar Dergisi, 17(2), 89-116.

TVB, (2001). "Ulaştırma Sektörü", Sektör Araştırmaları Serisi No:24 (http://www.vakifbank.com.tr/earastirma/ulastirma.doc), Türkiye Vakıflar Bankası T.A.O. Planlama ve İktisadi Araştırmalar Grup Yönetmenliği.

UBAK-İTÜ (2004a). Ulaștırma Ana Planı Stratejisi- .I.Ara Rapor, Ulaştırma ve Ulaşım Araçları UYG-AR Merkezi, İstanbul.

UBAK-İTÜ (2004b). Ulaştırma Ana Planı Stratejisi- .II.Ara Rapor, Ulaştırma ve Ulaşım Araçları UYG-AR Merkezi, İstanbul. 
WHITNAH, D.R. (1998). US Department of Transportation. Greenwood Press, Westport CT, USA.

WINSTON, C. (2010). Last exit: Privatization and Deregulation of the US Transportation System. Brooking Institution Press, Washington, DC.

WRIGHT, R.O. (2004). Chronology of Transportation in the United States. McFarland, North Carolina, USA. 